\title{
Polska, bolszewicy i „biała” Rosja - z wschodniej polityki Francji (1918-1921)
}

Zarys treści: Po I wojnie światowej Polska, dążąc do ukształtowania swoich granic wschodnich, walczyła z Rosją. Francja z uwagi na tradycje sojusznicze z niepokojem obserwowała sytuację w Rosji po 1917 r. Ponieważ Francja była antybolszewicko nastawiona, istniała wprawdzie szansa na wsparcie polskich dążeń na wschodzie, ale cele francuskiej i polskiej polityki zagranicznej zbyt różniły się w sprawach rosyjskich. Francja zwalczała Rosję Sowiecką i wspierała „białych” generałów. U podstaw takiej polityki występowało dążenie do reaktywowania ważnego dla Francji aliansu na wschodzie.

Summary: After World War I Poland was fighting against Russia, trying to determine its eastern borders, and France, with growing concern because of its traditional alliances, was observing the situation in Russia after 1917. There was a chance, because of anti-Bolshevik attitude of France, that it would support Polish aspirations in the east, but there were too great differences between Polish and French aims in their Russian affairs. In the following years France was against the Soviet Russia and supported „White” generals. This was driven by France's attempts to reactivate the most important eastern alliance.

Słowa kluczowe: francuska dyplomacja, wschodnia polityka Francji, stosunki polsko-francuskie, Francja-Rosja Sowiecka, Francja - „biała” Rosja”, kordon sanitarny.

Keywords: french diplomacy, eastern policy of France, Polish-French relations, France-Soviet Russia, France - „white” Russia, sanitary cordon.

\section{Wstęp}

W czasie konferencji w Spa 10 VII 1920 r. premier Francji Alexandre Millerand powiedział do premiera Wielkiej Brytanii Davida Lloyda George’a „trzeba zrobić wszystko, aby zachować Polskę". Słowa te odzwierciedlają tylko jeden z elementów francuskiej polityki zagranicznej po I wojnie światowej i nie zawierają najważniejszego jej aspektu, 
czyli poparcia Francji dla „białej” Rosji i jej antybolszewickiego stanowiska. W niniejszym artykule problemy te zostaną poruszone w kontekście postaw i działań francuskiej dyplomacji w jej stosunkach z Polską i rzeczywistym poparciem Francji dla niepodległego państwa polskiego. Nie zostaną omówione, a przedstawione już w ogólnym zarysie $\mathrm{w}$ literaturze, stosunki francusko-polskie, $\mathrm{w}$ tym oficjalne stanowisko Francji wobec samej idei niepodległego państwa polskiego, kontaktów z Komitetem Narodowym Polskim czy rozmów poprzedzających podpisanie polsko-francuskiego sojuszu ${ }^{1}$. Problemem niezwykle trudnym i w konsekwencji bardzo niekorzystnym dla Polski był fakt, iż pomimo zbieżności z Francją w ocenie bolszewizmu, we francuskiej polityce wschodniej zabrakło długofalowego poparcia dla polskiej polityki na Wschodzie. Zaprezentowany tekst, oparty w dużym stopniu na nowych materiałach, stanowi jedynie niewielki fragment badań dotyczących wschodniej polityki Francji.

Stan badań nad zagadnieniami stosunków francusko-polskich i francusko-sowieckich w latach 1918-1921 jest wprawdzie pod niektórymi względami zadowalający, ale nie dysponujemy dobrze udokumentowanymi i pełnymi monografiami. W historiografii polskiej mamy jedynie pracę Józefa Kukułki, Francja a Polska po traktacie wersalskim 1919-1922 (Warszawa 1975). Publikacja ta, chociaż rażąca w warstwie interpretacyjnej, broni się pod względem dostępnych wówczas materiałów źródłowych. Weryfikacji jednak należy poddać przypuszczenie Kukułki o pewnym wsparciu Francji dla Polski w przygotowaniach do kampanii kijowskiej ${ }^{2}$. Należy przypomnieć, że to Piotr Wandycz jako jeden z pierwszych badaczy wysunął tezę o krytycznym stanowisku Francji wobec polskich przedsięwzięć militarnych na wschodzie w 1920 r. Analizy idące w podobnym kierunku przeprowadzili także Norman Davies i Kalervo Hovi. Ten ostatni zajął polemiczne stanowisko wobec tezy M. Carleya Jabary o przychylności Francji wobec polskich ofensywnych działań na wschodzie ${ }^{3}$. Ważnymi pracami, w których poświęcono wiele miejsca problematyce polsko-francuskiej i francusko-sowieckiej, do których będziemy jeszcze nawiązywać, są między innymi publikacje właśnie Piotra Wandycza, Anny Cienciały, Tytusa Komarnickiego, Andrzeja Nowaka ${ }^{4}$. Historiografia francuska poświęciła do tej pory

1 W. Rojek, Wplyw mocarstw sprzymierzonych i stowarzyszonych na historyczno-polityczna geneze II Rzeczypospolitej VIII 1914 - II/VI 1919, [w:] Naród - Państwo. Europa Środkowa w XIX i XX wieku. Studia ofiarowane Michałowi Pułaskiemu w pięćdziesięciolecie pracy naukowej, red. A. Patek i W. Rojek, Kraków 2006, s. 125-135; M. Leczyk, Komitet Narodowy Polski a Ententa i Stany Zjednoczone 1917-1919, Warszawa 1966; J. Pajewski, Wokół sprawy polskiej. Paryż - Lozanna - Londyn 1914-1918, Poznań 1970; J. Kukułka, Francja a Polska po traktacie wersalskim 1919-1922, Warszawa 1975.

2 J. Kukułka, op. cit., s. 162.

3 P. Wandycz, France and Her Eastern Allies 1919-1925: French - Czechoslovak - Polish Relations from the Paris Peace Conference to Locarno, Minneapolis, Westport 1962; M. Jabara Carley, The Politics of Anti-bolshevism: The French Government and the Russo-Polish War, December 1919 to May 1920, „The Historical Journal", nr 19 (1/1976); K. Hovi, Alliance de revers: Stabilization of France's Alliance Policies in East Central Europe 1919-1921, Turku 1984; N. Davies, White Eagle, Red Star. The Polish-Soviet War 1919-1920, New York 1972.

4 P. Wandycz, The French Barrière de l'Est or Cordon Sanitaire, [w:] Wilsonian East Central Europe. Current Perspectives, ed. J. S. Micgiel, New York 1995; idem, France and Her Eastern Allies 1919-1925...; 
mało miejsca stosunkom francusko-rosyjskim w okresie 1918-1921. Dużo lepiej wyglądają badania dotyczące okresu późniejszego, po nawiązaniu francusko-sowieckich stosunków dyplomatycznych po 1924 r. Maxime Mourin publikacją z 1967 r. Les relations franco-sovietiques 1917-1967 zapoczątkował francuskie badania nad tą problematyką. Praca ta opiera się wprawdzie na wąskiej bazie źródłowej, i to przede wszystkim francuskiej, zawiera jednak dużo faktografii, daje wgląd w najważniejsze zagadnienia. Ważna, ale także bazująca na dokumentacji francuskiej, jest praca Anne Hogenhuis-Seliverstoff, Les relations franco-sovietiques 1917-19245. Autorka ta należy obecnie do zespołu przygotowującego publikację Documents Diplomatiques Français za lata 1920-19216. Do tych źródeł, zasygnalizowanych po raz pierwszy polskiemu czytelnikowi przez Andrzeja Nowaka, będziemy wielokrotnie jeszcze wracać, stanowią one bowiem ważny zbiór dający wgląd w politykę zagraniczną Francji.

\section{Francuskie działania polityczno-militarne wobec Rosji po $1917 \mathrm{r}$.}

Przypomnijmy, iż zawarty przez Francję z Rosją w końcu XIX wieku antyniemiecki sojusz polityczno-wojskowy stanowił jeden z ważniejszych elementów jej polityki zagranicznej. Ten wschodni filar francuskiej dyplomacji zaczął chwiać się już w lutym w 1917 r. po obaleniu cara, uległ destrukcji po dojściu do władzy bolszewików w październiku 1917 r. Przez następne lata Francja zwalczała Rosję bolszewików i wspierała „białych” generałów. U podstaw takiej polityki występowało dążenie do reaktywowania ważnego dla Francji aliansu na wschodzie. Jednocześnie Francja dokonywała zmian w polityce zagranicznej, popierając na konferencji paryskiej w 1919 r. powstanie nowych państw na gruzach imperium rosyjskiego, w tym szczególnie Polski, oraz zaczęła konstruować nowe sojusze. Francuski badacz Georges-Henri Soutou ${ }^{7}$ włączył czasy zwycięskiej I wojny dla Francji do okresu, który określił „smutkiem mocarstwa”. Pomimo ogromnego wysiłku zbrojnego i dyploma-

A. Cienciała, T. Komarnicki, From Versailles to Locarno. Keys to Polish Foreign Policy, 1919-1925, Lawrence 1984; A. M. Cienciała, Mocarstwa wobec Europy Wschodniej 1914-1939. Przeglad publikacji, „Zeszyty Historyczne”, z. 39, 1977, s. 203-210; J. Doise, M. Vaïsse, Politique étrangère de la France. Diplomatie et outil militaire 1871-1991, Paris 1992; K. Hovi, Cordon sanitaire or barrière de l'Est? The Emergence of the New French Eastern European Alliance Policy 1917-1919, Turku 1975; M. Jabara Carley, op. cit.; J. Kukułka, op. cit., M. Leczyk, op. cit.; J. Pajewski, op. cit.; A. Nowak, Polska i trzy Rosje. Studium polityki wschodniej Józefa Piłsudskiego (do kwietnia 1920), Warszawa 2001.

5 A. Hogenhuis-Seliverstoff, Les relations franco-sovietiques 1917-1924, Paris 1981.

6 Documents Diplomatiques Français [dalej DDF] 1920, t. I (10 janvier - 18 mai 1920), Paris 1997; t. II (19 mai - 23 septembre 1920), Paris 1999; t. III (24 septembre 1920 - 15 janvier 1921), Bruxelles 2002, + Annexes (10 janvier 1920-31 décembre 1921), Bruxelles 2005; DDF, Annexes (10 janvier 1920 - 31 décembre 1921), Bruxelles 2005. O zawartości tych tomów, ich znaczeniu dla badania francuskiej polityki zagranicznej i stosunków międzynarodowych po I wojnie światowej pisał A. Nowak, Documents diplomatiques français - źródła do politycznej historii wojny polsko-sowieckiej w 1920 roku, „Dzieje Najnowsze”, 3/2006, s. 145-151.

7 G.-H. Soutou, Le deuil de la puissance (1914-1958), [w:] Histoire de la diplomatie française, présentation de Dominique de Villepin, Perrin, Paris 2005, s. 745-862. 
tycznego, Francja wyszła z tej wojny osłabiona, chociaż nadal chciała brylować na kontynencie, pełnić rolę arbitra. Utrata rosyjskiego alianta w 1917 r. doprowadziła do włączenia przez premiera i ministra wojny Georgesa Clemenceau na początku wariantu atlantyckiego, czyli wparcia się na USA, ale po $1919 \mathrm{r}$. został on zaniechany i ponownie dominowała we francuskiej dyplomacji opcja europejska, czyli sojusz na kontynencie. Realizacja tego głównie antyniemieckiego projektu zw. 4 filarami, czyli systemu sojuszów Francji z Polską, Czechosłowacją, Jugosławią i Rumunią, nastąpiła dopiero w $1921 \mathrm{r}$. i w latach następnych.

Przypomnijmy także, że jeszcze w czasie działań wojennych w Europie w 1918 r. wojska Ententy wylądowały w Murmańsku i Władywostoku. Głównym celem tej operacji była próba rekonstrukcji frontu wschodniego przeciwko Niemcom. Uczyniono to dodatkowo w sytuacji, kiedy już w marcu $1918 \mathrm{r}$. bolszewicy podpisali z Niemcami w Brześciu Litewskim pokój ${ }^{8}$. Po zerwaniu w listopadzie 1918 r. przez bolszewików ustaleń brzeskich Francuzi przegrupowali siły wojskowe na południe Rosji. W listopadzie 1918 r. narodziła się także idea kordonu sanitarnego (zaadaptowana przez aliantów w marcu-kwietniu 1919 r., ale w praktyce funkcjonująca od grudnia 1919 r.), czyli tworzenia defensywnego antybolszewickiego frontu skupiającego państwa na zachodzie Rosji (Polska, Finlandia, państwa bałtyckie, Ukraina /?/, Czechosłowacja, Rumunia). Dodatkowo Francja, wspierając generałów Antona Denikna, Nikołaja Judenicza i admirała Aleksandra Kołczaka, miała nadzieję na zachowanie związków z dawnym aliantem rosyjskim i wyeliminowanie groźnych dla porządku europejskiego bolszewików. Tym bardziej że w marcu 1919 r. w Moskwie Lenin i jego współpracownicy utworzyli III Międzynarodówkę (Komintern) i planowali eksport rewolucji na inne państwa. Jak zostało już powiedziane, Francja i Wielka Brytania wyraziły zgodę w czasie konferencji paryskiej na utworzenie kilku państw położonych w przedwojennych granicach Rosji, Niemiec i Austro-Węgier. Państwa te, w tym Polska, stały się jednym z elementów nowego ładu międzynarodowego. Jednak nawet amputowana terytorialnie Rosja, po wyeliminowaniu bolszewików, mogła nadal być sojusznikiem Francji.

Premier Georges Clemenceau w piśmie do ministra spraw zagranicznych Stephena Pichona z 23 X 1918 pisał na temat bolszewików: „ta nowa i wynaturzona forma imperializmu przygniata Europę niebezpieczeństwem tym groźniejszym, że pojawia się ono dokładnie w chwili, gdy rychły koniec wojny nieuchronnie wywoła w każdym z krajów poważny kryzys gospodarczy i socjalny. Jeśli Ententa pozostawia Niemcom - którym groźba ta zagraża w pierwszym rzędzie i którzy pragną się przed nią zabezpieczyć - troskę o jej likwidację po tym, jak sami ją wywołali, umożliwia im ona $w$ krótkim okresie powetowanie załamania, jakiego doznali na Zachodzie, poprzez utworzenie na Wschodzie państwa rosyjskiego, które - uwolnione przez nich od anarchii - stałoby się niebawem otwarte na niemiecką ekspan-

82 XII 1917 r. w Brześciu bolszewicy podpisali z Niemcami zawieszenie broni. W obradach brała udział także delegacja Ukraińskiej Republiki Ludowej. Pokój zawarto 3 III 1918 r. Podpisały go także Austro-Węgry, Turcja i Bułgaria. 
sję gospodarczą i związane z nimi sojuszem politycznym, zostałoby tym sposobem najwspanialszą zdobyczą pangermanizmu. Jest więc niezbędnym, by Alianci, o ile pragną zachować owoce swego zwycięstwa, wzięli na siebie wywołanie, poprzez upadek Sowietów, odrodzenia Rosji. W praktyce można to osiągnąć bez przenoszenia wojny do Rosji Centralnej - poprzez gospodarcze okrążenie bolszewizmu"' . List ten dobrze ilustruje francuską analizę zagrożenia bolszewickiego nie tylko dla Francji, ale i dla Europy. Clemenceau obawiał się ekspansji niemieckiej na tereny rosyjskie i ewentualnego sojuszu niemiecko-sowieckiego. U podstaw wrogości Francji wobec Rosji bolszewików występowało dążenie do osłabienia Niemiec. Francja chciała silnej Rosji niezwiązanej z Niemcami. Aby ten cel osiągnąć, potrzebowała wsparcia Ententy, a szczególnie Wielkiej Brytanii.

Francja i Wielka Brytania, złączone sojuszem antyniemieckim w czasie wojny, po 1918 r. zajmowały coraz bardziej odmienne stanowiska w polityce europejskiej. Można powiedzieć, że zarówno jedno, jak i drugie mocarstwo powróciło do swej tradycyjnej polityki, aczkolwiek w przypadku Francji następowało tworzenie nowych konstrukcji sojuszniczych na wschodzie ${ }^{10}$. Opierając się na podstawowych do tej tematyki badaniach Hovi'ego z pracy Cordon sanitaire or barrière de l'Est? The Emergence of the New French Eastern European Alliance Policy 1917-1919, możemy powiedzieć, że od końca 1918 r. we francuskiej strategii bezpieczeństwa na Wschodzie Europy występowały dwa elementy ściśle ze sobą powiązane: tworzenie kordonu sanitarnego oraz wspieranie „białych” generałów walczących z bolszewikami. Występowało w tym dodat-

9 Za K. Hovi, Cordon sanitaire or barrière de l'Est?..., s. 148-149. Pismo Clemenceau do Pichona z 23 X 1918.

10 Problem stosunków brytyjsko-francuskich po I wojnie światowej wiąże się z tworzeniem i funkcjonowaniem nowego ładu europejskiego i został już gruntownie przedstawiony w literaturze. Podobnie dość szeroko opisano już wschodnią politykę mocarstw po I wojnie światowej, w tym miejsce Polski w tworzonym systemie międzynarodowym. Przykładowa literatura to: A. Wolfers, Britain and France between two Wars: Conflicting Strategies of Peace since Versailles, New York 1940; W. MacDougall, France's Rhineland Diplomacy, 1914-1924: The Last Bid for a Balance of Power in Europe, Princeton 1978; P. M. H. Bell, France and Britain, 1900-1940: Entente and Estrangement, London-New York 1996; P. Cohrs, The Unfinished Peace after World War I, Cambridge 2006; S. Marks, The Illusion of Peace, 1919-1929, Palgrave Macmillan 2003; E. du Réau, Lordre mondial, de Versailles à San Francisco (juin 1919-juin 1945), Paris 2007; S. Schirmann, Quel ordre européen. De Versailles à la chute du IIIe Reich, Paris 2006; Bâtir une nouvelle sécurité. La coopération militaire entre la France et les Etats d'Europe centrale et orientale de 1919 à 1929: acte du colloque de décembre 1999, Château de Vincennes 2001; T. Sandu, Le système de sécurité français en Europe centre-orientale: l'exemple roumain: 1919-1933, Paris 1999; S. Żerko, System wersalski i próby jego modyfikacji w latach dwudziestych, „Przegląd Zachodni” 2008, nr 4, s. 13-34; P. Łossowski, Traktat wersalski a Europa Środkowo-Wschodnia, [w:] Od Wersalu do Poczdamu. Sytuacja międzynarodowa Europy Środkowo-Wschodniej 1918-1945, red. A. Koryn, Warszawa 1996, s. 9-17; H. Bułhak, Sojusze systemu wersalskiego: Warszawa-Paryż-Budapeszt-Praga, [w:] Od Wersalu do Poczdamu..., s. 43-63; P. Wandycz, The French Barrière de l'Est or Cordon Sanitaire, [w:] idem, France and Her Eastern Allies 1919-1925...; A. Cienciała, T. Komarnicki, op. cit.; A. M. Cienciała, Mocarstwa wobec Europy Wschodniej 1914-1939. Przegląd publikacji, „Zeszyty Historyczne”, z. 39, 1977, s. 203-210; J. Doise, M. Vaïsse, op. cit.; K. Hovi, Cordon sanitaire or barrière de l'Est?...; M. Jabara Carley, op. cit.; M. Nowak-Kiełbikowa, Polska-Wielka Brytania w l. 1918-1923, Warszawa 1975; T. Piszczkowski, Anglia a Polska 1914-1939, Londyn 1975; J. Kukułka, op. cit.; M. Leczyk, op. cit.; J. Pajewski, op. cit. 
kowo dążenie do wyeliminowania Niemców z Rosji i przeciwdziałanie współpracy rosyjsko-niemieckiej, a także obrona francuskich interesów ekonomicznych w Rosji ${ }^{11}$.

W związku z tą sytuacją 12 XII 1919 r. w Londynie odbyła się konferencja premierów Lloyda George’a i Clemenceau oraz ambasadorów USA i Włoch w Londynie na temat utworzenia kordonu sanitarnego przeciwko Rosji bolszewickiej składającego się z Polski, Finlandii, państw bałtyckich aż po Kaukaz oraz przeciwdziałania zacieśniania związków pomiędzy Rosją i Niemcami. Polska miała być jednym z najważniejszych elementów kordonu przeciwko bolszewikom, pełnić rolę bariery i „szachować” Niemcy w ich dążeniach do wpływania na sytuację w państwach bałtyckich i na Górnym Śląsku ${ }^{12}$. Był to niewątpliwy sukces Clemenceau, gdyż jeszcze dzień wcześniej Lloyd George w rozmowie z nim wyrażał wiele sceptycyzmu wobec tych koncepcji. Powątpiewając w ewentualny marsz bolszewików w kierunku zachodnim, uważał, że państwa graniczące z Rosją (limitrofy), takie jak Polska, powinny przygotować się do zawarcia pokoju z bolszewikami ${ }^{13}$.

Zwolennikiem idei kordonu sanitarnego był nie tylko premier Clemenceau, ale także marszałek i przewodniczący Najwyższej Rady Wojennej Ferdinand Foch. Obaj widzieli w Polsce ważny element konstrukcji systemu bezpieczeństwa Francji. Przypomnijmy, iż do Polski przybyła już w lutym 1919 r. Misja Międzysojusznicza wysłana przez Radę Najwyższą z byłym ambasadorem Francji w Rosji Noulensem i gen. Niesselem ${ }^{14}$. Francuska Misja Wojskowa w Polsce ostatecznie ukształtowała się jednak dopiero w kwietniu 1919 r., kiedy kierownictwo objął gen. Paul-Prosper Henrys ${ }^{15}$. Poparcie dla Polski wynikało z francuskiej strategii bezpieczeństwa na wschodzie i miało charakter antyniemiecki i antybolszewicki. Polska stanowiła barierę przeciwko niemieckiej ekspansji na wschód oraz była ważnym ogniwem kordonu sanitarnego przeciwko Rosji bolszewickiej, ale także częścią francuskich planów interwencyjnych na terenie Rosji ${ }^{16}$.

11 K. Hovi, Cordon sanitaire or barrière de l'Est?..., s. 149-151. Hovi rozpatruje także projekt kordonu sanitarnego jako odwróconą wersję dawnej francuskiej koncepcji bariery na wschodzie przed Niemcami, którą tworzyła Rosja oraz jako przeciwdziałanie porozumienia niemiecko-rosyjskiego. Szeroko także N. Jordan, La barrière de l'Est, „Revue d'histoire diplomatique” 2001, nr 3, s. 54.

12 Dokumenty i materiały do historii stosunków polsko-radzieckich, t. 2: Listopad 1918 - kwiecień 1920, red. N. Gąsiorowska-Grabowska, I. A. Chrienow, oprac. W. Gostyńska et al., Warszawa 1961 [dalej DiM], dok. 275, s. 488-493, Londyn 12 XII 1919, protokół z konferencji premiera rządu brytyjskiego D. Lloyd George’a z premierem rządu francuskiego G. Clemenceau oraz ambasadorami Stanów Zjednoczonych i Włoch w Londynie; Documents on British Foreign Policy 1919-1939 [dalej DBFP], seria I, t. II, s. 745-748. Szerzej o konferencji K. Hovi, Alliance de revers..., s. 19-20.

13 Archives du Ministère des Affaires étrangères français [dalej AMAEF], Russie, 213, k. 30-36, Londyn 12 XI 1919 /pod dokumentem/, notatka z rozmowy Clemenceau z Lloydem George'm z 11 XI 1919 o 6 wieczorem. W spotkaniu udział wziął także francuski minister spraw zagranicznych Pichon.

14 S. Sierpowski, Działalność Misji Międzysojuszniczej w Polsce w 1919 r., „Dzieje Najnowsze” 2013, nr 3, s. 3-24.

15 Szerzej T. Schramm, Francuskie Misje Wojskowe w państwach Europy Środkowej 1919-1938, Poznań 1987.

16 K. Hovi, Cordon sanitaire or barrière de l'Est?..., podrozdziały: Francuski program dla Polski oraz Miejsce Polski we francuskim systemie bezpieczeństwa, s. 152-156, 190-196; P. Wandycz, France and Her Eastern Allies 1919-1925..., s. 36-44. 
Państwem, które zainicjowało zmianę stanowiska wobec Rosji bolszewików w kierunku nawiązywania z nimi kontaktów, na początku głównie handlowych, była Wielka Brytania. W listopadzie i grudniu 1919 r. Brytyjczycy prowadzili w Kopenhadze z przedstawicielami bolszewików tajne rozmowy, które zapoczątkowały wymianę obywateli (więźniów brytyjskich na terenie Rosji) i utorowały drogę do wznowienia kontaktów gospodarczych. Z uwagi na wsparcie przez Ententę „białej” Rosji strona francuska była zaniepokojona tym faktem. Stanowisko takie przedstawił dyrektor do spraw politycznych we francuskim ministerstwie spraw zagranicznych Philippe Berthelot 23 XI 1919 r. w telegramie do ambasadora Francji w Londynie Paula Cambona i zasugerował mu zakomunikowanie tego oraz zwrócenie uwagi na więźniów francuskich na terenie Rosji w Foreign Office ${ }^{17}$. Przypomnijmy, iż 16 I 1920 r. Rada Najwyższa na wniosek Brytyjczyków uchwaliła wniosek o zniesieniu blokady gospodarczej z Rosją i ponownym rozpatrzeniu sprawy zawarcia traktatu handlowego z Rosją bolszewicką. W styczniu 1920 r. nastąpiła zmiana francuskiej ekipy rządowej. 17 I 1920 r. zakończyła się kadencja prezydenta Raymonda Poincaré. Jego następcą został Paul Deschanel. 18 I 1920 r. Clemenceau złożył dymisję z funkcji premiera i ministra wojny, a 21 I na stanowisku premiera zastąpił go Alexandre Millerand. Na Quai d'Orsay wspomagał go sekretarz generalny ministerstwa, dawny ambasador Francji w Piotrogrodzie, Maurice Paléologue. Natomiast bliski współpracownik Clemenceau Philippe Berthelot pozostał wprawdzie na stanowisku dyrektora spraw politycznych, ale jego rola uległa znacznemu osłabieniu. Należy jednak zaznaczyć, iż Francja w okresie Clemenceau zaangażowała się w analogiczny proces jak Brytyjczycy, czyli negocjacji z bolszewikami, mający na celu sprowadzenie swoich obywateli z terenów rosyjskich oraz akcję humanitarną dla nich ${ }^{18}$. Ekipa Milleranda pozostawała nadal antybolszewicka, pokładano również duże nadzieje w możliwości przejęcia władzy przez „białą” Rosję. Millerand sądził, iż bolszewicy upadną. Należy zgodzić się w tym miejscu z tezą Carleya, do której nawiązuje także Hovi, iż Quai d’Orsay chciało samo rozegrać sytuację w Rosji, problemem była granica polsko-rosyjska i fakt, że Polska nie chciała współpracować z „białą” Rosją ${ }^{19}$.

\section{Polskie próby sondowania Francji w przypadku wojny lub ewentualnych pertraktacji pokojowych z bolszewikami oraz stanowisko Francji}

Polski minister spraw zagranicznych Stanisław Patek udał się do Francji w końcu grudnia 1919 r. w celu wysondowania francuskiego stanowiska wobec bolszewików zarówno w wariancie walki z nimi, jak i nadesłanych przez nich 22 XII $1919 \mathrm{r}$. propozycji pokojowych. 31 XII 1919 r. odbył rozmowę z Philipem Berthelotem. Francuski dyplomata kategorycznie odrzucał pomysł jakichkolwiek rozmów czy

17 DDF, 1920, t. 1, s. 11, informacje w przypisie do dok. 7.

18 DDF, 1920, t. 1, Paryż 13 I 1920, telegram Clemenceau do ministra Francji w Kopenhadze Claudela, dok. 9, s. 13.

19 M. Jabara Carley, op. cit., s. 166. Podobne stanowisko prezentuje K. Hovi, Alliance de revers..., s. $19-21$. 
negocjacji z bolszewikami, powiedział nawet, że „Francja nigdy nie pertraktowałaby z Sowietami: uważałaby ona bolszewików za bandę zbójców, którzy zagarnęli władzę przemocą, narzucili dominację terrorem, popełnili zbrodnie wszelkiego autoramentu, zdezorganizowali na długo życie socjalne i gospodarcze Rosji. Nie należy więc $\mathrm{z}$ nimi pertraktować $\mathrm{w}$ żaden sposób, gdyż oznaczało by to pośrednie uznanie słuszności ich zbrodni oraz legalności ich rządów. Jeśliby nasi sojusznicy z nimi pertraktowali lub rozpoczęli negocjacje moglibyśmy jedynie nad tym ubolewać na nich składając całą odpowiedzialność za taką słabość. Bolszewicy nie szanują własnych zobowiązań, co wynika $\mathrm{z}$ ich zasad wykluczających możliwość przywiązywania do nich najmniejszej wagi”"20. Patek otrzymał więc niezwykle zdecydowaną odpowiedź sugerującą stronie polskiej niepodejmowanie żadnych rozmów z bolszewikami. Berthelot nie rozpoczął $\mathrm{z}$ nim jednak rozmowy na temat ewentualnych scenariuszy na przyszłość. Patek rozmawiał jeszcze z premierem Clemenceau, marszałkiem Fochem, a potem nowym premierem Millerandem. Francuscy rozmówcy, zachowując antybolszewickie stanowisko, zapewniali o wsparciu dla Polski, ale tylko w przypadku ataku bolszewików. Millerand, podobnie jak Berthelot, wyraził negatywną opinię na temat zawierania przez Polskę pokoju z bolszewikami. Powiedział, iż to nie gwarantuje bezpieczeństwa $\mathrm{z}$ ich strony, a stanowi jedynie manewr i należy spodziewać się, że w sytuacji korzystnej dla siebie mogą Polskę zaatakować ${ }^{21}$. Millerand w instrukcji dla nowego posła francuskiego w Warszawie Panafieu z 4 III 1920 r., czyli już w czasie, kiedy strona polska podjęła decyzję przystąpienia do rozmów pokojowych z bolszewikami, nie wierzył nadal w sukces tych rokowań, ale uważał iż „rząd warszawski winien uwzględniać przede wszystkim własny interes i jeżeli nie możemy mu doradzać nie zawierania pokoju, to tym bardziej nie możemy doradzać jego zawarcia" 22 . W przypadku jednak kontynuowania rozmów i negocjacji pokojowych polsko-bolszewickich uważał, że Francja powinna starać się nakłaniać Polskę do niestawiania zbyt wygórowanych ambicji terytorialnych na wschodzie (granice z 1772 r. jako „nierozsądne”). Należy jednak podkreślić, pomimo krytycznego stosunku francuskiego premiera do polskich planów przywrócenie granic na wschodzie z 1772 r., że widział on w Polsce rzeczywistego sojusznika w oporze przeciwko Rosji bolszewickiej. Był zdecydowany pomóc Polsce w przypadku ataku bolszewickiego, ale z uwagi na polskie "niedoświadczenie” w polityce, stał na stanowisku wpływania, doradzania polskiemu rządowi. Millerand prowadził także rozmowy z przeciwnikiem bolszewików, dążącym do współpracy z Polską, Borisem Sawinkowem. W liście do Piłsudskiego Sawinkow pisał: „Zapewnił mnie [Millerand] kategorycznie, że w razie napadu bolszewików na Polskę, rząd francuski okaże Polsce poparcie i pomoc. Dodał, że jest tego zdania, że gdyby sojusz pomiędzy patriotyczną Rosją a Polską, Finlandią i państwami granicznymi doszedł do skutku, to bolszewizm byłby rozbity. Powiedział, że w tym wypadku Francja poparłaby i dopomogła nie tylko

20 AMAEF, Russie, 286, 31 XII 1919, k. 56-57, notatka Berthelota z rozmowy z Patkiem.

21 DDF, 1920, t. I, dok. 123, s. 197, telegram Milleranda do Jusseranda, Paris 16 II 1920.

22 DDF, 1920, t. 1, dok. 200, s. 293, Paris 4 III 1920, Instrukcja Milleranda do Panafieu. 
Polsce, lecz i Rosji. Oświadczy jednak, że nie będzie w stanie nic uczynić, jeżeli Polska zgodzi się na pokój z bolszewikami"23. Sawinkow zabiegał oczywiście o wsparcie Francji dla swoich koncepcji politycznych. Użycie przez niego w cytowanym liście stwierdzenia, że Millerand był przeciwnikiem zawierania pokoju z bolszewikami jest ważne. Premier w cytowanej już instrukcji dla Panafieu pisał, że gdyby alianci zadecydowali o wsparciu dla Polski w przypadku ataku bolszewickiego, doradzanie Polsce przez Francję zawarcia pokoju z Sowietami byłoby niewskazane ${ }^{24}$. Sawinkow cenił Milleranda właśnie za takie wyczekiwanie. W liście do Piłsudskiego z 14 III pisał nawet: „Dzięki Millerandowi sprzymierzeńcy powstrzymali się od natychmiastowego nawiązania stosunków politycznych z bolszewikami, dzięki niemu nie wywarto jeszcze bardziej stanowczego nacisku na Polskę w sensie zawarcia pokoju"25. Sawinkow krytykował natomiast Lloyda George’a za politykę wahań wobec Rosji² ${ }^{26}$.

Pomimo wyraźnie antybolszewickiego stanowiska we francuskiej polityce zagranicznej na początku 1920 r., atmosfera wokół polskiej polityki na wschodzie stawała się coraz bardziej ciężka, a różnice opinii i poglądów na temat Rosji i stosunków polsko-rosyjskich w kołach dyplomatyczno-wojskowych rozbieżne. Poseł francuski w Warszawie Eugène Pralon w telegramie do Clemenceau z 3 I 1920, pisząc o przygotowaniach Piłsudskiego do wojny z Rosją, określał je jako „imperialne” wynikające $\mathrm{z}$ „polskiej megalomanii”, widział w tym zagrożenie dla całego systemu międzynarodowego ${ }^{27}$. O ile Pralon właściwie odmawiał Polsce prawa do prowadzenia samodzielnej polityki na wschodzie, o tyle zupełnie inaczej podchodzono do polityki Piłsudskiego w kręgach wywiadowczo-wojskowych. Na Polskę patrzono głównie przez pryzmat strategicznych celów Francji po utracie alianta rosyjskiego, widziano w bolszewizmie realne zagrożenie dla Europy ${ }^{28}$. Gen. Henrys informował marszałka Focha 30 XII 1919 r. o przygotowywanej przez bolszewików ofensywie przeciwko Polsce ${ }^{29}$. W kolejnych raportach do Focha Henrys pisał o Polsce jako „Etat tampon” przeciwko bolszewikom i sugerował wsparcie Polski (głównie w sprzęt wojenny) w jej konflikcie z bolszewikami. Z korespondencji gen. Henrysa z marszałkiem Fochem z początku 1920 r. wyłania się obraz szerokich planów francuskiego kierownictwa wojskowego utworzenia wspólnego frontu limitrofów przeciwko bol-

23 List Sawinkowa do Piłsudskiego, Paryż 8 II 1920, [w:] J. Cisek, Sąsiedzi wobec wojny 1920 roku. Wybór dokumentów, Londyn 1990, s. 93.

24 DDF, 1920, t. 1, dok. 200, s. 293-295, Paris 4 III 1920, Instrukcja Milleranda do Panafieu.

25 List Sawinkowa do Piłsudskiego, Paryż 14 III 1920, [w:] J. Cisek, op. cit., s. 97.

26 AAN, MSZ, 21, Z rozmowy p. Wielowiejskiego [Wielowieyskiego] z p. Rochem, s. 17.

27 AMAEF, Russie, 286, k. 47, 17 XII 1919 telegram Pralona do Clemenceau; tamże k. 65, 3 I 1920 telegram Pralona do Clemenceau; DDF, 1920, t. I, telegram Pralona do Clemenceau 19 I 1920, s. 46-47; szeroko o korespondencji Pralona (telegramy z 3, 12 i 29 I) piszą: M. Jabara Carley, op. cit., s. 170-172; A. Cienciała, T. Komarnicki, op. cit., s. 167; A. Nowak, Polska i trzy Rosje..., s. 440.

28 AMAEF, Russie, 286, k. 24-28, Raport 2em Bureau z 3 XII 1919. Podkreślano, iż Piłsudski dąży do reaktywowania dawnych granic polskich. Wskazywano jednocześnie na znaczenie strategiczne Polski dla Francji po utracie alianta rosyjskiego.

29 AMAEF, Russie, 286, k. 53-54, telegramy Henrysa do Focha nr. 971, 972 z 30 XII 1919. 
szewikom ${ }^{30}$. Henrys w nocie sporządzonej 4 I 1920 r. i przesłanej Fochowi ostrzegał przed groźbą ataku bolszewickiego na Polskę, państwa bałtyckie i Rumunię (w dalszej konsekwencji także na wschód lub zachód) i sugerował wzmocnienie „aktualnej bariery tworzonej przez państwa antybolszewickie" ${ }^{31}$. Henrys pisał o konieczności przekazania przez państwa Ententy materiałów wojskowych dla tych państw oraz nawiązywał do myśli Focha - większej koordynacji państw tworzących barierę antybolszewicką i utworzenia wspólnego przez nich dowództwa. Sugestie Henrysa szły w kierunku tworzenia potężnego, defensywnego frontu zjednoczonych państw opasających Rosję od zachodu po południe, wspieranego przez Ententę. Jednocześnie Ententa powinna wspomagać akcję polityczną w Rosji mającą na celu obalenie bolszewików. Henrys sugerował doprowadzenie do współdziałania armii polskiej z siłami rosyjskimi antybolszewickimi w Rosji, które miałoby za zadanie zmianę sytuacji politycznej w Rosji ${ }^{32}$. Korespondencja pomiędzy Fochem i Henrysem oraz pisma Focha do Clemenceau $\mathrm{z}$ tego okresu wskazują na dużą determinację strony francuskiej mającą na celu zarówno wzmocnienie frontu wschodniego jako zapory o charakterze defensywnym, jak i prowadzenie działań militarnych na terenach Rosji w celu obalenia bolszewików ${ }^{33}$. W związku z klęskami generałów Judenicza, Denikina i admirała Kołczaka oraz obawą o umocnienie się bolszewików w Rosji Henrys i Foch dążyli do szybkiej realizacji tych planów. W piśmie do Clemenceau z 15 I 1920 r. Foch nawiązał do sugestii Henrysa, doradzał poruszenie tych spraw na forum mocarstw sprzymierzonych. Foch miał nadzieję na zaakceptowanie ich przez państwa Ententy. Niestety plany te zostały pod naciskiem Brytyjczyków odrzucone kilka dni później na forum Rady Najwyższej.

Można przypuszczać, że pod wpływem postawy Londynu Quai d’Orsay, pomimo nadal antybolszewickiego stanowiska, zaczęła nieznacznie modyfikować swoje stanowisko w sprawie działań na Wschodzie. Jules Laroche, wicedyrektor departamentu Europy, 20 I 1920 r. przygotował notę zatytułowaną Les États limitrophes de la Russie et les bolcheviks ${ }^{34}$. Dokument dotyczył Polski, Rumunii, Finlandii i konfliktu tych państw z Rosją. Zostało w nim wyrażone stanowisko aliantów mające polegać na nieangażowaniu się w ten konflikt i niepopieraniu jakichkolwiek ofensywnych działań przeciwko rządowi sowieckiemu oraz niemieszaniu się $\mathrm{w}$ wewnętrzne sprawy Rosji. Laroche pisal jedynie o wsparciu „moralnym” i „pomocy materialnej” dla państw zaatakowanych przez bolszewików. W nocie poruszono także kwestie ewentualnej współpracy, „porozumienia” o charakterze defensywnym Polski, Rumunii i Finlandii oraz przychylności mocarstw wobec takiego projektu, ale nie ich udziału. Ciekawym dokumentem ilustrującym także francuski punkt widzenia jest Nota

30 AMAEF, Russie, 286, k. 70-84, Paryż 4 I 1920, Note relative à la situation en Russie et au mode d'action politique et militaire de l'Entente et des Etats limitrophes de la Russie bolcheviste contre le Gouvernement des Soviets, podpis Henrysa.

31 Ibidem, k. 71.

32 Ibidem, k. 72-77.

33 DDF, 1920, t. 1, dok. 18, s. 26-27.

34 DDF, 1920, t. I, dok. 32, s. 50, Paris 20 I 1920, Note de M. Laroche. 
dawnego konsula generalnego Francji w Rosji, kierownika działu rosyjskiego na Quai d'Orsay Josepha Fernanda Grenarda z 24 I 1920 r. Według niego rola aliantów powinna obecnie ograniczać się do obserwowania, wyczekiwania na wykrystalizowanie się sytuacji w Rosji, przy zachowaniu czujności, aby Armia Czerwona nie posuwała się na zachód i nie stanowiła zagrożenia dla Europy. Grenard pisał, iż wszystko wskazuje na umacnianie się bolszewików, ale nie potrafił udzielić odpowiedzi na pytanie, czy Rosja będzie państwem federalnym czy jednolitym? Grenard popierał ideę kordonu - związku państw powstałych na zachodnich obszarach dawnego imperium rosyjskiego jako bariery przed bolszewizmem. Dodawał do niego jeszcze jedno państwo - białą Rosję - ale ze znakiem zapytania. Związek ten miałby mieć charakter wyłącznie obronny i byłby najprawdopodobniej kontrolowany przez aliantów, wspierany przez nich finansowo i militarnie (uzbrojenie, personel techniczny). Problemem dla Grenarda była jednak Polska. Obawiał się jej ofensywnej polityki wobec Rosji i dlatego zalecał wyperswadowanie Polsce zbyt dużych aspiracji na wschodzie ${ }^{35}$.

\section{Polska - wbrew Francji - prowadzi samodzielną politykę na Wschodzie}

Polska jednak odpowiedziała bolszewikom na ich propozycje pokojowe i opracowała warunki pertraktacji. Było to posunięcie trudne i ryzykowne nie tylko z powodu braku wiarygodności bolszewików, ale także nieuznawania ich na arenie międzynarodowej przez inne państwa. Ostrożność wobec podjęcia przez Polskę pertraktacji $\mathrm{z}$ bolszewikami zalecał także poseł polski w Paryżu Maurycy Zamoyski. W raporcie z 8 II 1920 r. przestrzegał, aby Polska, podpisując pokój z bolszewikami, nie postawiła się w sytuacji ,jedynego państwa alianckiego, które uznało rząd bolszewicki” i zalecał, aby podpisanie pokoju nastąpiło dopiero po „wyjaśnieniu się stanowiska Aliantów do bolszewizmu" 36 . Powoływał się także na rozmowę z Millerandem z 8 II 1920 r., w czasie której francuski premier przestrzegał, aby nie ufać bolszewikom, gdyż nie dotrzymują słowa ${ }^{37}$.

13 III 1920 r. Stanisław Patek wręczył noty posłom Francji, Wielkiej Brytanii, Stanów Zjednoczonych i Włoch przedstawiające zarys ogólnych zasad do ewentualnych rozmów pokojowych $\mathrm{z}$ bolszewikami ${ }^{38}$. Strona francuska zachowała milczenie wobec samego faktu podjęcia przez Polskę decyzji o przystąpieniu do tych rozmów. Krytycznie odnosiła się jednak wobec polskich żądań granicznych na wschodzie. W raporcie z 18 III 1920 r. Zamoyski pisał Patkowi o narastającym na Quai d’Orsay, po klęskach Kołczaka i Denikina, przeświadczeniu umacniania się

35 DDF, 1920, t. I, dok. 46, s. 70, Paris 24 I 1920, Note de M. Grenard sur la question russe.

36 AAN, Ambasada RP w Paryżu, sygn. 151, k. 79. Paryż 8 II 1920, raport nr 51 Zamoyskiego do Patka.

37 Ibidem.

38 DiM, t. II, dok. 352, s. 677-678, Warszawa [15 III 1920], nota ministra spraw zagranicznych RP St. Patka do posła brytyjskiego w Polsce H. Rumbolda powiadamiająca o warunkach, na jakich rząd polski gotów jest podjąć pertraktacje pokojowe z rządem radzieckim. Nota z 13 III, a nie 15 III. 
bolszewików i tym samym bezcelowości dalszej walki z nimi. Zamoyski informował także o coraz większym „odosobnieniu politycznym Francji wśród aliantów”, czyli różnicach zdań pomiędzy nią a Wielką Brytanią i Włochami w ocenie sytuacji w Rosji. Polski dyplomata sądził, że bez względu na to, w jakim kierunku pójdzie modyfikacja polityki francuskiej wobec Rosji, Paryż był przeciwny zbyt daleko idącym rewindykacjom polskim na wschodzie ${ }^{39}$.

Strona polska wprawdzie zdawała sobie sprawę z życzliwości Focha, doceniała antybolszewickie stanowisko Milleranda, ale francuski premier i minister spraw zagranicznych był wtedy przeciwny zawieraniu pokoju z bolszewikami. Zresztą sam plan przystąpienia do rozmów pokojowych z bolszewikami był dla Polski - z międzynarodowego punktu widzenia - ryzykowny. Przystąpienie do negocjacji z bolszewikami na temat ustalania wzajemnych granic i regulowania stosunków oznaczałoby uznanie ich jako prawowitej władzy w Rosji. Ententa nie uznawała przecież formalnie rządu bolszewików, chociaż takie tendencje istniały w Londynie. Millerand w wystąpieniu w Izbie Deputowanych 6 II 1920 r. powiedział, iż Polska uzyska wsparcie sprzymierzonych tylko w przypadku ataku bolszewików. W pierwszych miesiącach 1920 r. Millerand w swojej polityce wobec Rosji i bolszewików kierował się następującymi zasadami: niemieszania się oficjalnie w wewnętrzne sprawy Rosji, nienawiązywania stosunków dyplomatycznych z rządem sowieckim, utrzymywanie stosunków ekonomicznych z ludnością rosyjską za pośrednictwem bolszewików z uwagi na potrzeby Europy Zachodniej (zboże, produkty żywnościowe), udzielenie wsparcia państwom sąsiadującym z Rosją $\mathrm{w}$ przypadku ataku na nie bolszewikó ${ }^{40}$. Przypomnijmy jeszcze, że w czasie posiedzenia Rady Najwyższej w Londynie 25 II 1920 r. potwierdzono stanowisko sprzymierzonych w sprawie udzielenia państwom sąsiadującym z Rosją Sowiecką wsparcia tylko w przypadku zaatakowania ich przez bolszewików oraz nieinterwencji w wewnętrzne sprawy Rosji ${ }^{41}$. 1 III 1920 r. natomiast w Londynie odbyła się Konferencja ekonomiczna z udziałem Lloyda George’a, Francesco Nittiego, a ze strony francuskiej ambasadora Cambona i Berthelota. Jej przebieg odzwierciedla znakomicie różnice w podejściu do Rosji bolszewickiej Wielkiej Brytanii i Włoch oraz Francji. Obaj premierzy, brytyjski i włoski, byli zgodni, iż problemy ekonomiczne Europy wymagają nawiązywania bliższych kontaktów gospodarczych z Rosją bolszewicką i uważali, iż należy zachęcać także państwa sąsiadujące z Rosją do zawarciu pokoju z Sowietami. Przeciwko tej opcji protestowali Francuzi opowiadający się za utrzymaniem linii nienawiązywania $z$ nimi stosunków dyplomatycznych. Berthelot powiedział nawet, iż z politycznego punktu widzenia wydaje się niebezpieczne „popychanie” państw sąsiadujących z Rosją do zawarcia pokoju

39 DiM, t. II, dok. 353, s. 679-681, Paryż 18 III 1920, pismo Zamoyskiego do Patka o stanowisku rządu francuskiego wobec polskiej polityki wschodniej.

40 DDF, 1920, t. 1, dok. 190, s. 276-277, Paris 1 III 1920, Telegram Milleranda do ministra Francji w Bukareszcie Daeschnera zatytułowany Politique à l'égard de la Russie.

41 Ibidem, s. 277. Millerand przytoczył także stanowisko Rady Najwyższej z 25 II. Komunikat z konferencji londyńskiej, [w:] DBFP, seria I, t. 7, s. 217-218. 
z bolszewikami. Sceptycznie odniósł się do polskich przygotowań pertraktacji $\mathrm{z}$ nimi, jak również do polskich planów spotkania z państwami bałtyckimi w celu podjęcia wspólnej decyzji wobec Rosji bolszewickiej. Relacjonujący to spotkanie nieobecnemu na konferencji Millerandowi Cambon pisał, iż należy spodziewać się ze strony Londynu i Rzymu dążenia do nawiązania stosunków dyplomatycznych z rządem sowieckim ${ }^{42}$. Kiedy Brytyjczycy zachęcali Francuzów do prowadzenia rozmów gospodarczych z bolszewikami, Paryż na początku odczytywał to jako jednoznaczny gest w kierunku uznania bolszewików i odmawiał brania w tym udziału $^{43}$. Można odnieść wrażenie, że wiosną 1920 r., a także później, toczyła się dyplomatyczna gra pomiędzy Francją i Wielką Brytanią na temat kontaktów z bolszewikami. Londyn, zachowując pozory współpracy z Paryżem, podkreślał ekonomiczny, a nie polityczny charakter spotkań z przedstawicielami bolszewików. Paryż natomiast mocno wskazywał, iż takie rozmowy mogą mieć tylko konsekwencje polityczne w kierunku uznania rządu bolszewików ${ }^{44}$. Jednak francuska dyplomacja świadoma dość zdecydowanej postawy Brytyjczyków wspieranych przez Włochów, zaczynała minimalnie ustępować i proponowała włączenie do rozmów z bolszewikami kwestii długów zaciągniętych we Francji przez Rosję carską przed 1917 r. i wysondowania w ten sposób stanowiska Moskwy w sprawach ich międzynarodowych zobowiązań ${ }^{45}$. Francja, pomimo zakazu nawiązywania stosunków gospodarczych z Rosją Sowiecką, brała pod uwagę ewentualność powołania specjalnych urzędników technicznych do spraw handlowych z Rosją. Urzędnicy ci mogliby kontaktować się tylko $\mathrm{z}$ analogicznymi po stronie rosyjskiej urzędnikami handlowymi niewystępującymi w imieniu rządu Sowietów ${ }^{46}$. Dodatkowo do Francuzów dochodziły informacje, że bolszewicy są w posiadaniu carskiego złota $^{47}$. Takie stanowisko nadal pełne rezerwy, ale dopuszczające minimalne stosunki handlowe z Sowietami, Francuzi przekazali Brytyjczykom. Wydaje się, że Quai d'Orsay bardziej dostosowywało się taktycznie do Londynu, niż rzeczywiście następowało jakieś przełamywanie oporów wobec bolszewików. Paryż pozostawał antybolszewicki, popierał gen. Piotra Wrangla i z niepokojem obserwował wrogi do tego przedstawiciela „białej” Rosji stosunek Londynu. Sondowano także polskie stanowisko wobec Wrangla i zachęcano do współpracy, ale nie podjęto żadnych oficjalnych ruchów ${ }^{48}$.

42 DDF, 1920, t. 1, dok. 193, s. 279-280, 2 III 1920, telegram ambasadora Francji w Londynie Paula Cambona do Milleranda.

43 DDF, 1920, t. II, dok. 38, s. 46-47, 28 V 1920, telegram ambasadora Francji w Londynie Paula Cambona do Milleranda. Cambon pisał o wizycie sowieckiego przedstawiciela w Londynie Krassina i dążeniach Brytyjczyków do prowadzenia z nim rozmów gospodarczych; ibidem, dok. 44, s. 53, Paryż 29 V 1920, telegram Milleranda do Cambona.

44 DDF, 1920, t. II, dok. 53, s. 62-63, Londyn 31 V 1920, telegram Cambona do Milleranda.

45 DDF, 1920, t. II, dok. 59, s. 70-71, Paryż 1 VI 1920, telegram Milleranda do Cambona i Barrére’a, ambasadora Francji w Rzymie.

46 DDF, 1920, t. II, dok. 83, s. 108, Paryż 7 VI 1920, telegram Milleranda do Cambona.

47 DDF, 1920, t. II, dok. 118, s. 148-150, Paryż 16 VI 1920, nota Grenarda.

48 AMAE, Russie, 289, k. 21, Paryż 2 VII 1920, telegram Milleranda do Panafieu. 
Francja, kwestionując polskie wysiłki zmierzające do przywrócenia granic z $1772 \mathrm{r}$. na wschodzie, krytycznie oceniła polską ofensywę na wschód i zajęcie Kijowa wiosną 1920 r., ale oficjalnie zachowała dystans wobec tego.

\section{„Zachować Polskę"}

Postawa Francji w kierunku większej aktywności w swej polityce wschodniej zaczęła się trochę zmieniać w sytuacji ofensywy armii bolszewickiej i groźby podboju przez nich państwa polskiego. Dlatego też w czasie konferencji w Spa, poświęconej niemieckim zobowiązaniom wynikającym $\mathrm{z}$ traktatu wersalskiego, Francja zajęła zdecydowanie bardziej radykalne stanowisko wobec bolszewików niż Wielka Brytania.

Przypomnijmy, że w połowie czerwca 1920 r. Armia Czerwona po zajęciu dużej części Ukrainy i zmuszeniu wojsk polskich do opuszczenia Kijowa kierowała się w stronę Warszawy. Jednocześnie część jej wojsk, przedzierając się wzdłuż granicy z Prusami Wschodnimi, stanowiła dodatkowe zagrożenie połączenia się z wojskami niemieckimi. W Polsce w końcu czerwca $1920 \mathrm{r}$. został powołany pozaparlamentarny rząd Władysława Grabskiego. Z inicjatywy premiera została stworzona Rada Obrony Państwa skupiająca wszystkie siły polityczne. Wobec zwycięstw bolszewików niepodległość państwa polskiego była zagrożona. Na początku lipca wyjechała do Spa delegacja polska $\mathrm{w}$ celu uzyskania wsparcia $\mathrm{w}$ walce $\mathrm{z}$ bolszewikami. Przewodniczył jej początkowo Stanisław Patek, potem premier Grabski, który 10 VII 1920 r. podpisał bardzo niekorzystne dla Polski warunki graniczne mające stanowić podstawę do rozmów $z$ bolszewikami. Pośrednikami w sporze polsko-bolszewickim mieli być Brytyjczycy, Francuzi wstrzymali się od tego. Są to fakty powszechnie wiadome, ale kryją się za tym mniej eksponowane w literaturze lub nieznane problemy związane $\mathrm{z}$ działaniami francuskiej dyplomacji w tym okresie.

Francuscy politycy w Spa w rozmowach między innymi ze Stanisławem Patkiem czy Władysławem Grabskim wprawdzie nadal krytycznie odnosili się do polskiej polityki wschodniej, ale realnie oceniali bolszewickie zagrożenie dla Polski i Europy. Należy jednak podkreślić, że Millerand i francuska delegacja nie rozmawiali w Spa z Polakami o swoich ewentualnych działaniach na wschodzie, jak również stosunku do rozmów pokojowych z bolszewikami. Patek zapisał nawet, że Millerand „z niezwykłą u siebie zajadłością zaatakował mnie (...) pytaniem, czy my jesteśmy istotnie szczerzy w postępowaniu z Rosją, jaka jest właściwie nasza polityka wobec Rosji”"49. Grabski natomiast odniósł wrażenie, iż premier Francji „unikał go” i „Francja opuściła Polskę w Spa"50. Francuzi omawiali problemy dotyczące konfliktu polsko-bolszewickiego w gronie polityków Ententy, a szczególnie z Brytyjczykami. To Lloyde George był partnerem dla Milleranda i to z nim próbował osiągnąć pewien kompromis w sprawach wschodnich. Strona francuska była generalnie nieprzychylnie

49 AAN, MSZ, sygn. 21, k. 5, Spa 6 VII 1920, raport Patka do ministra spraw zagranicznych E. Sapiehy.

50 AAN, Akta Władysława Grabskiego, sygn. 13, k. 7-8. 
nastawiona do pomysłu pośrednictwa w ewentualnych pertraktacjach pokojowych pomiędzy Polakami i Rosją Sowiecką. Millerand przekonywał Brytyjczyków, iż bolszewicy dążą przede wszystkim do całkowitego pokonania i zlikwidowania Polski i wcale nie oczekiwali takiego pośrednictwa Ententy. Premier Francji był skłonny pełnić rolę pośrednika w konflikcie polsko-bolszewickim razem z Brytyjczykami, ale tylko pod warunkiem wymuszenia zgody na rządzie Sowietów przyjęcia przez nich zobowiązań międzynarodowych poprzednich rządów, czyli uznania między innymi długów Francji w Rosji ${ }^{51}$. Jego słowa skierowane głównie do Lloyda George’a brzmiały: „trzeba zrobić wszystko aby zachować Polskę, ale trzeba zrobić wszystko co jest użyteczne i praktyczne" 52 . Na to żądanie Francuzów nie chciał zgodzić się brytyjski premier, sądząc zapewne, iż skomplikuje to, a może uniemożliwi podjęcie negocjacji z bolszewikami. Tym bardziej że sowiecka delegacja z Leonidem Krasinem i Lwem Kamieniewem już czekała w Londynie. Różnice zdań dotyczyły także kluczowych dla Polski spraw, czyli samych warunków ewentualnych rozmów polsko-sowieckich i tutaj Francuzi, tak przynajmniej wynika z zapisu francuskiego, a nie brytyjskiego, starali się forsować polski punkt widzenia. Lloyde George domagał się od Polski wycofania się do „linii wyznaczonej w Paryżu w grudniu 1919 r. przez Radę Najwyższą". Z uwagą do tego określenia wystąpił towarzyszący Millerandowi dyrektor polityczny Quai d'Orsay Philippe Berthelot, dowodząc, iż została ona określona przez Radę Najwyższą jedynie jako „linia minimum”, czyli nie była linią definitywną. Dodatkowo oponował francuski dyplomata, Rada Najwyższa zgodziła się na zajęcie Galicji Wschodniej przez Polskę, a tereny te nie zostały uwzględnione dla Polski w linii z 1919 r. $^{53}$

Francuzi, jak wiadomo, nie złożyli podpisu pod słynną notą Curzona do rządu sowieckiego z 11 VII 1920 r., udzielili natomiast później Polsce niewielkiego wsparcia militarnego (głównie w postaci broni i amunicji oraz udziału wojskowych wchodzących w skład Francuskiej Misji Wojskowej czy przybycia gen. Maxima Weyganda i mjr. Charlesa de Gaullea) w wojnie z bolszewikami. To Brytyjczycy w Spa stali się pośrednikami w próbie doprowadzenia do rozejmu Polski z Rosją Sowiecką. Bolszewicy jak wiadomo odrzucili tę notę. Postawiło to Ententę w nowej sytuacji wobec konfliktu Polski z bolszewikami. Brytyjczycy zaproponowali jednak Sowietom spotkanie w Londynie ${ }^{54}$. Dodatkowo $\mathrm{z}$ ich inicjatywy do Polski przybyła specjalna misja brytyjsko-francuska w celu zbadania sytuacji. Millerand przekazał

51 DDF, Annexes, dok. 41, Spa, 10 VII 1920, s. 380; ibidem, dok. 40, Spa, 10 VII 1920, s. 379. Millerand domagał się włączenia do telegramu do Sowietów następującego zdania: „Etats voisins la participation du gouvernement des Soviets à une conférence internationale impliquant qu'il accepte les engagements des gouvernements russes antérieure à l'égard des pays étrangers".

52 Ibidem, s. 381.

53 Ibidem, s. 382. Ten zapis wygląda inaczej w Documents on British Foreign Policy, 1919-1939, first series, vol. VIII, s. 516. Wynika z niego, iż Berthelot wypowiedział słowa „linia minimalna”, ale dodał, iż nie wiadomo, czy była nią dla strony polskiej czy rosyjskiej. Na różnicę w zapisie francuskim i brytyjskim zwrócił już uwagę A. Nowak, Documents diplomatiques français..., s. 150.

54 Szerzej M. Nowak-Kiełbikowa, op. cit., s. 214-218. 
swym wysłannikom, że w przypadku kontynuowania przez bolszewików ataku i prób narzucenia Polsce swego rządu alianci wesprą Polskę ${ }^{55}$. Jak wiadomo 23 VII 1920 r. ludowy komisarz spraw zagranicznych Rosji Sowieckiej Cziczerin przesłał notę do Curzona akceptującą pomysł odbycia spotkania w Londynie z przedstawicielami państw Ententy, ale z wykluczeniem udziału Polski i omawiania spraw polsko-sowieckich ${ }^{56}$. Przeciwko temu stanowisku wystąpiła Francja. Paryż rozważał wprawdzie wariant partycypacji w takim spotkaniu, ale z udziałem Polski i sąsiednich państw ( $w$ tekście „les gouvernements qui se sont constitués en fait sur le territoire de l'ancienne Russie") ${ }^{57}$. Kluczowe rozmowy pomiędzy Millerandem a Lloydem Georgeem na ten temat odbyły się w Boulogne-sur-Mer 27 VII 1920. To premier Francji zajął bardzo zdecydowane stanowisko w sprawie udziału Polski w tej konferencji. Lloyd George mówił jedynie o rozpatrywaniu tam spraw polskich. Millerand, podkreślając zagrożenie, jakie dla wszystkich państw Ententy stanowią bolszewicy, domagał się ponownie postawienia im szeregu warunków przed rozpoczęciem ewentualnej konferencji. Dotyczyły one wspomnianego już udziału Polski, ale także przyjęcia międzynarodowych zobowiązań zaciągniętych przez poprzednie rządy rosyjskie, zmiany stanowiska Sowietów wobec gen. Wrangla (co rzeczywiście brzmi kuriozalnie) ${ }^{58}$. Ostatecznie, z uwagi na obiekcje francuskiego premiera, Brytyjczycy zrezygnowali z pierwotnego pomysłu zwołania takiej konferencji. W oficjalnym komunikacie podano, iż konferencja mogłaby się odbyć w przypadku udziału w niej Polski i państw sąsiednich ${ }^{59}$. Dwa dni później, czyli 29 VII 1920 r., francuska Rada Ministrów podjęła uchwałę, iż „Francja nie dopuści do zagłady swego sprzymierzeńca - Polski" ${ }^{60}$. Poparcie Francji dla Polski w jej konflikcie z bolszewikami, próba pośrednictwa w ewentualnych rokowaniach pokojowych polsko-sowieckich ze strony Wielkiej Brytanii, wynikało w dużym stopniu z chęci ochrony nowego systemu międzynarodowego zapoczątkowanego postanowieniami konferencji paryskiej, którego Polska była istotnym elementem.

Nie ulega wątpliwości, iż Francja potrzebowała Wielkiej Brytanii do swej polityki antybolszewickiej. Można postawić pytanie, czego tak naprawdę oczekiwał Millerand, do czego dążył w czasie rozmów z Brytyjczykami? Czy to była tylko chęć uzyskania dyplomatycznego wsparcia w utrzymaniu antybolszewickiego stanowiska, czy może

55 DDF, 1920, t. II, dok. 225, s. 292, Paryż 21 VII 1920, telegram Milleranda do ambasadora Francji w Waszyngtonie (przebywającego w Paryżu) Jelesa Jusseranda. W skład misji francuskiej wchodzili: Jusserand, szef Sztabu Generalnego Wojskowego Komitetu Międzysojuszniczego gen. Maxime Weygand, dyrektor gabinetu Milleranda Alfred Vignon; w skład misji brytyjskiej wchodzili: ambasador w Berlinie lord Edgar d'Abernon, gen. Percy Radcliffe, sekretarz gabinetu Lloyda George'a sir Maurice Hankey. Na temat tej misji szerzej J. Kukułka, op. cit., s. 214-217.

56 Dokumienty Wnieszniej Politiki SSSR, t. III, Moskwa 1959, s. 61-62. Pisze o tym także J. Kukułka, op. cit., s. 217.

57 DDF, 1920, t. II, dok. 244, s. 310-311, Paryż 25 VII 1920, Note du Département.

58 DDF, Annexes, dok. 52-53, sprawozdanie z rozmów w Boulogne-sur-Mer 27 VII 1920, s. 423-433.

59 DDF, 1920, t. II, dok. 257, s. 330-331, Paryż 28 VII 1920, telegram Milleranda do Panafieu. O tym spotkaniu pisze także J. Kukułka, op. cit., s. 218.

$60 \mathrm{Za} \mathrm{J.} \mathrm{Kukułka,} \mathrm{op.} \mathrm{cit.,} \mathrm{s.} 220$. 
sondowanie Londynu co do możliwości powrotu do wariantu wojennego? Czytając dokumentację z tego okresu, można odnieść wrażenie, iż premier Millerand oczekiwał od Lloyda George’a bardziej zdecydowanych działań. Premier brytyjski powiedział w czasie spotkania w Hythe 9 VIII 1920 r., iż dla jego rządu tak samo trudno jest zdecydować się na wojnę z bolszewikami jak Francji na pokój ${ }^{61}$. W świetle dostępnych mi dokumentów nigdzie jednak nie padło z ust Milleranda nawoływanie do bezpośredniego zaangażowania się Ententy w konflikt militarny z bolszewikami. Francuski polityk mówił jedynie o konieczności zachowania Polski, udzielenia jej wsparcia wojskowego, wyrażał nieufność wobec rządu bolszewików i sprzeciwiał się dążeniu do uznania ich na arenie międzynarodowej. Jedyne co Francji udało się osiągnąć z Brytyjczykami w sprawie jej polityki wschodniej to wspólne oświadczenie mówiące o woli ratowania niepodległej Polski w "granicach etnograficznych" w czasie konferencji w Hythe w dniach 8 i 9 VIII 1920 r. $^{62}$ Francja, popierając gen. Wrangla i uznając go oficjalnie 10 VIII 1920 r., nie chciała uczestniczyć w polsko-sowieckich pertraktacjach pokojowych. Uznając rząd gen. Wrangla i podkreślając zagrożenie, jakie stanowili dla Europy bolszewicy, Francja zajmowała zupełnie odmienne stanowisko w sprawach rosyjskich niż Wielka Brytania. Wynikało to niewątpliwie z jej dążenia do odzyskania strat finansowo-gospodarczych poniesionych w Rosji (sprawa długów wojennych i nacjonalizacji przedsiębiorstw francuskich w Rosji) i prowadzenia rozmów tylko z takim rządem, który godziłby się podjąć te kwestie. Wielka Brytania natomiast, dążąc do zakończenia formowania nowego porządku międzynarodowego, w którym miałaby nadal ważny głos na kontynencie europejskim, była skłonna uznać bolszewików za prawowitą władzę w Rosji. Francja nie zmieniła swego stanowiska po odejściu we wrześniu 1920 r. Milleranda i zastąpieniu go przez Georgesa Leyguesa. 1 X 1920 r. pisał on w instrukcji do Panafieu, iż Francja będzie wspierać Polskę w jej obronie przed bolszewikami i przestrzegać przed zawarciem rujnującego pokoju („paix désastreuse”). Określenie to dotyczyło zbyt wygórowanych polskich ambicji granicznych na wschodzie. Leygues powtarzał stosowane od dawna określenie na Quai d'Orsay o „etnograficznej granicy” Polski na wschodzie oraz przywiązywaniu dużej wagi przez Francję do stosunku Polski do gen. Wrangla ${ }^{63}$. Francja wyczekiwała na sukcesy Wrangla, czyli przejęcie przez niego kontroli w Rosji i stąd dystansowanie się przez nią do polskich tendencji zawarcia pokoju z bolszewikami. Kiedy Panafieu przekazał francuskiemu ministrowi spraw zagranicznych informacje, z podaniem przewidywanej linii granicznej polsko-sowieckiej, o podpisaniu przez Polskę i Rosję Sowiecką 8 X 1920 r. preliminariów pokojowych w Rydze ${ }^{64}$, Leygues przyjął to nie tylko krytycznie, ale rozważał uczynienie démarche razem z Brytyjczykami przeciwko rozpościeraniu przez Polskę nadmiernie swego terytorium na wschodzie ${ }^{65}$. Wbrew

61 DDF, Annexes, dok. 56, s. 438, zapis Milleranda z rozmów w Hythe 9 VIII 1920.

62 DDF, 1920, t. II, dok. 331, s. 424, Paryż 11 VIII 1920, telegram Milleranda do placówek dyplomatycznych na temat postanowień tej konferencji. Pisze o tym także J. Kukułka, op. cit., s. 223-225.

63 DDF, 1920, t. III, dok. 23, s. 28, Paryż 1 X 1920, telegram Leyguesa do Panafieu.

64 Ibidem, dok. 51, s. 70-71, Warszawa 8 X 1920 telegram Panafieu do Leyguesa.

65 Ibidem, dok. 53, s. 73, Paryż 11 X 1920, telegram Leyguesa do Panafieu. 
oficjalnemu stanowisku rządu, francuskie kręgi gospodarcze zaczęły jednak zastanawiać się nad modyfikacją stanowiska wobec bolszewików po klęskach Wrangla. U podstaw tego myślenia występowała obawa przed zdominowaniem handlu z Rosją Sowiecką przez Wielką Brytanię. Francuzi obawiali się zawarcia nawet jakiegoś tajnego porozumienia gospodarczego pomiędzy Moskwą i Londynem ${ }^{66}$. Z uwagą śledzono wszystko co działo się w polityce międzynarodowej wokół Rosji Sowieckiej. $\mathrm{W}$ końcu $1920 \mathrm{r}$. tendencje te nie spotkały się z akceptacją premiera i ministra spraw zagranicznych, który cały czas podkreślał fakt nieczynienia pretekstu i nieuznawania w żadnej formie rządu sowieckiego ${ }^{67}$. Francuzi dystansowali się od toczących się w Rydze rozmów pokojowych polsko-sowieckich. Nie zajęli oficjalnego stanowiska wobec podpisanych preliminariów pokojowych ani później po podpisaniu pokoju w Rydze. Popierając cały czas „białą” Rosję, zachowywali dystans wobec wschodniej granicy Polski ${ }^{68}$.

Francja uznała i nawiązała kontakty dyplomatyczne z ZSRR dopiero w $1924 \mathrm{r}$. Wcześniej, bo w marcu 1921 r., Polska zawarła pokój ryski z Rosją i Ukrainą Sowiecką, w lutym 1921 r. Francja zawarła sojusz polityczno-wojskowy z Polską. Wprawdzie Francja nadal popierała „białą” Rosję, ale wydaje się, że to okres 1918-1921 był kluczowym dla niej w prowadzeniu aktywnej antybolszewickiej polityki. Po $1921 \mathrm{r}$. słabły szanse na zmianę rządów w Rosji, wobec kolejnych państw nawiązujących stosunki dyplomatyczne z ZSRR Francja pozostawała coraz bardziej osamotniona. Trzeba jednak podkreślić, że politycy francuscy posiadali dużą wiedzę na temat bolszewików i prawidłowo przewidywali ich działania. Francja nie uzyskała jednak wsparcia w swej antybolszewickiej polityce ze strony Wielkiej Brytanii, jej polityka tylko w części odpowiadała Polsce. Dążąc do obalenia bolszewików, wspierała, wbrew polskim planom i interesom, „białych” generałów.

\section{Poland, Bolsheviks and "White" Russia - eastern policy of France (1918-1921)}

The Anti-German Alliance, signed between France and Russia at the end of the 19th century, was one of the most important elements of French foreign policy. Having overthrown the Tsar, the eastern pillar of French diplomacy began to be unstable in February 1917 and was destroyed in October 1917 after the Bolsheviks came to power. For years, France fought the Bolsheviks in Russia and supported the "white" generals. The fundamental aim of this policy was to strive for reactivating the important alliance in the East. Simultaneously, supporting a creation of new states on the ruins of the Russian Empire particularly Poland at the Paris Peace Conference in 1919, France made changes in their foreign policy. They began to draw up new alliances and did not manage to involve Great Britain into their anti-Bolshevik policy successfully. These united

66 Ibidem, dok. 261, s. 378-380, Paryż 1 XII 1920, list Chevilly d'Humilly attaché handlowego (dyrektor biura) na Rosję i limitrofy do Auguste’a Isaaca ministra handlu i przemysłu.

67 Ibidem, dok. 283, s. 404-405, Paryż 8 XII 1920, telegram Leyguesa do wszystkich placówek dyplomatycznych.

68 DDF, 1921, t. I, dok. 76, s. 118-119, 4 II 1921, Note du Département; M. Wołos, Francja a traktat ryski, [w:] Traktat ryski 1921 roku po 75 latach, studia pod red. M. Wojciechowskiego, Toruń 1998, s. 263-264. 
countries took different views in European policy after 1918. France, despite similar interests with Poland in Bolshevism assessment, did not develop a long-term support for the Polish policy in the East. Contrary to Polish plans and interests, France supported "white" generals in order to overthrow the Bolsheviks. They established diplomatic relations with the USSR in 1924. Earlier, in March 1921, Poland signed the Peace of Riga with the Soviet Union, and in February 1921, France entered into a political and military alliance with Poland. It is true that France still supported "White" Russia, but it seems that the period of 1918-1921 was crucial for conducting an active anti-Bolshevik policy. After 1921, chances to change Russian rule weakened and in reference to other countries entering into diplomatic relations with the Soviet Union, France remained alone.

Translated by Marta Antoniuk

\section{Польша, большевики и «белая» Россия - из восточной политики Франции (1918-1921)}

Заключенный между Францией и Россией в конце XIX века антинемецкий политико-военный союз являлся одним из важнейших элементов ее иностранной политики. Эта восточная опора французской дипломатии начала шататься уже в феврале 1917 г. после свержения царя и подверглась разрушению после прихода к власти в октябре 1917 г. большевиков. В течение следующих лет Франция боролась против большевистской России и поддерживала «белых» генералов. В основе такой политики лежало стремление реактивировать важный для нее альянс на востоке. В то же время Франция меняла свою иностранную политику, поддерживая на Парижской конференции в 1919 г. создание новых государств на развалинах российской империи, в том числе особенно Польши, а также начала создавать новые союзы. Она безуспешно пыталась втянуть в свою антибольшевистскую политику Великобританию. Эти государства, соединенные во время войны антинемецким союзом, после 1918 г. занимали все более противоположные позиции в европейской политике. Франция, несмотря на совпадающую с польской оценку большевизма, не разработала стратегию долгосрочной поддержки польской политики на востоке. Стремясь к свержению большевиков, она поддерживала, вопреки польским планам и интересам, «белых» генералов. Франция признала и установила дипломатические отношения с СССР только в 1924 г. Раньше же, в марте 1921 г., Польша заключила Рижский мир с советской Россией, а в феврале 1921 г. Франция заключила политико-военный союз с Польшей. Хотя Франция продолжала поддерживать «белую» Россию, но период 1918-1921 гг. был для нее ключевым в ведении активной антибольшевистской политики. После 1921 г. шансы на смену правительства в России уменьшались, из-за очередных государств, устанавливающих дипломатические отношения с СССР, а Франция становилась все больше одинокой.

Перевод Агнешка Поспишьль

\section{Bibliografia}

Cienciała A., Komarnicki T., From Versailles to Locarno. Keys to Polish Foreign Policy, 1919-1925, Lawrence 1984.

Davies N., White Eagle, Red Star. The Polish-Soviet War 1919-1920, New York 1972.

Doise J., Vaïsse M., Politique étrangère de la France. Diplomatie et outil militaire 1871-1991, Paris 1992.

Hogenhuis-Seliverstoff A., Les relations franco-sovietiques 1917-1924, Paris 1981. 
Hovi K., Alliance de revers: Stabilization of France's Alliance Policies in East Central Europe 1919-1921, Turku 1984; tenże, Cordon sanitaire or barrière de l'Est? The Emergence of the New French Eastern European Alliance Policy 1917-1919, Turku 1975.

Leczyk M., Komitet Narodowy Polski a Ententa i Stany Zjednoczone 1917-1919, Warszawa 1966. Łossowski P., Traktat wersalski a Europa Środkowo-Wschodnia, [w:] Od Wersalu do Poczdamu. Sytuacja międzynarodowa Europy Środkowo-Wschodniej 1918-1945, red. A. Koryn, Warszawa 1996, s. 9-17.

Kukułka K., Francja a Polska po traktacie wersalskim 1919-1922, Warszawa 1975.

Jabara Carley M., The Politics of Anti-bolshevism: The French Government and the Russo-Polish War, December 1919 to May 1920, „The Historical Journal”, nr 19 (1/1976).

Nowak A., Polska i trzy Rosje. Studium polityki wschodniej Józefa Piłsudskiego (do kwietnia 1920), Warszawa 2001.

Rojek W., Wplyw mocarstw sprzymierzonych i stowarzyszonych na historyczno-polityczna geneze II Rzeczypospolitej VIII 1914 - II/VI 1919, [w:] Naród - Państwo. Europa Środkowa w XIX i XX wieku. Studia ofiarowane Michałowi Pułaskiemu w pięćdziesięciolecie pracy naukowej, red. A. Patek i W. Rojek, Kraków 2006, s. 125-135.

Soutou G.-H., Le deuil de la puissance (1914-1958), [w:] Histoire de la diplomatie française, présentation de Dominique de Villepin, Perrin, Paris 2005, s. 745-862.

Sandu T., Le système de sécurité français en Europe centre-orientale: l'exemple roumain: 1919-1933, Paris 1999.

Żerko S., System wersalski i próby jego modyfikacji w latach dwudziestych, „Przegląd Zachodni” 2008, nr 4, s. 13-34.

Wandycz P., France and Her Eastern Allies 1919-1925: French - Czechoslovak - Polish Relations from the Paris Peace Conference to Locarno, Minneapolis, Westport 1962; tenże, The French Barrière de l'Est or Cordon Sanitaire, [w:] Wilsonian East Central Europe. Current Perspectives, ed. J. S. Micgiel, New York 1995.

Documents Diplomatiques Français [dalej DDF] 1920, t. I (10 janvier - 18 mai 1920), Paris 1997; t. II (19 mai - 23 septembre 1920), Paris 1999; t. III (24 septembre 1920 - 15 janvier 1921), Bruxelles 2002, + Annexes (10 janvier 1920-31 décembre 1921), Bruxelles 2005; DDF, Annexes (10 janvier 1920 - 31 décembre 1921), Bruxelles 2005.

Dr hab. Małgorzata Gmurczyk-Wrońska - prof. nadzw. w Instytucie Historii im. Tadeusza Manteuffla PAN, w Zakładzie Dziejów Dyplomacji i Systemów Totalitarnych. Pola badawcze: stosunki międzynarodowe, dyplomacja, polska, francuska i sowiecka polityka zagraniczna. 